\section{Knowledge of occupational hazards, and safety practices among butchers in Kano metropolis, Kano State, Nigeria}

\author{
Auwal Umar Gajida, ${ }^{1}$ \\ Usman Muhammad Ibrahim, ${ }^{2}$ \\ Zubairu Iliyasu, ${ }^{1}$ Rabiu Ibrahim Jalo, ${ }^{1}$ \\ Aminatu Kwakwu Chiroma, ${ }^{2}$ \\ Fatima Abubakar Saidu ${ }^{3}$ \\ ${ }^{1}$ Department of Community Medicine, \\ Bayero University and Aminu Kano \\ Teaching Hospital, Kano State; \\ ${ }^{2}$ Department of Community Medicine, \\ Aminu Kano Teaching Hospital, Kano \\ State; ${ }^{3}$ Faculty of Clinical Sciences, \\ Bayero University, Kano State, Nigeria
}

\section{Abstract}

Abattoir work is associated with significant public health hazards that result in occupational related diseases or aggravate the existing ill-health of non-occupational origin. This study assessed knowledge of occupational hazard, safety and hygienic practices among butchers in Kano Metropolis. Descriptive cross-sectional study design was used to study 321respondents in Kano metropolis. Data was collected using semi-structured interviewer administered questionnaire and analyzed at univariate, bivariate and multivariate levels using IBM SPSS version 22. The mean age of the respondents was $37.7 \pm 10.5$ years. More than a third $(35.8 \%)$ of the respondents were between the age ranges of 30 to 39 years. Overall, more than three-quarters $241(75 \%)$ of the respondents had good knowledge of occupational hazard, cut/injuries was known by most of the respondents 309 (96.3\%), while getting secondary infections from sustained wound and contracting diseases from infected animals were known by $241(75.1 \%)$ and 211 $(65.7 \%)$ of the respondents respectively. There was statistically significant association between knowledge of occupational hazard and having at least primary education $(\mathrm{P}=0.003)$, being in meat business for between 6 to 10 years $(\mathrm{P}=0.048)$ and selflearning of meat business (0.005). Respondents with formal education were $24 \%$ more likely to have good knowledge of occupational hazard [AOR $=1.24,95 \%$ CI (1.02-1.50)]. Being in meat business for at least 6 years was associated with $95 \%$ increase in knowledge of occupational hazard $[\mathrm{AOR}=0.95,95 \% \mathrm{CI}(0.58-1.55)]$. Self-learning of butchering was associated with $70 \%$ increased likelihood $[\mathrm{AOR}=0.7$, $95 \%$ CI (0.39-1.11)] of having good knowledge. Butchers selling meat in the restaurant were 7 times more likely to observe safety practices $[\mathrm{AOR}=6.9,95 \%$ CI (2.2421.01)]. This study revealed a good knowledge of occupational hazard among the butchers which is influenced by having formal education, duration in, and self-learning of the business, but safety practice was fair. Therefore, underscores the importance of formal training and supervision of butchers by relevant stakeholders to promote safety and hygienic practices. Government should therefore ensure regular training and supervision of butchers to promote safety and hygienic practice in order to prevent diseases.

\section{Introduction}

Work has its positive health-promoting effects, such as the financial dividend providing the worker with the basic necessities of life. There is, however, a reciprocal and interactive relationship between workers and the work environment. Although knowledge of these interactions between work and health is fundamental in understanding and practice of occupational health and safety, the importance of safety at the workplace is often overlooked. ${ }^{1-3}$

Abattoir work is associated with health hazards that could result in occupational diseases or may aggravate the existing ill health of non-occupationalorigin, ${ }^{4}$ with zoonosis gradually becoming a major global threat to public health and animal welfare. 5,6 Occupational infections mostly contracted by abattoir workers could be caused by iatrogenic or by transmissible agents, including viruses, bacteria, fungi, and parasites; and their toxins. ${ }^{4}$ Again, while manipulating body parts of large animals and lifting heavy equipment, workers could stress their muscles and joints, thus subjecting them to severe physical stress and pain, predisposing them to musculoskeletal disorders and other ailments. ${ }^{4}$ About 250 million cases of occupational injuries and illnesses occur annually worldwide, with prevalence studies from Botswana, Zimbabwe, Zambia, Ghana and Nigeria suggesting a high occurrence of occupational disease in Africa. ${ }^{3}$

The number of occupational infections that occur each year is largely unknown as a result of underreporting especially in developing countries. ${ }^{7}$ It has been estimated that over 120 million occupational accidents with over 200,000 fatalities occur each year in these countries. Sub-Saharan Africa appears to have the highest rate followed by
Correspondence: Usman Muhammad Ibrahim, Department of Community Medicine, Aminu Kano Teaching Hospital, PMB 3452 Kano State, Nigeria.

E-mail: usmanmi2000@gmail.com

Key words: Knowledge, Occupational Hazard, Safety-Practice, Butchers.

Contributions: The authors contributed equally.

Conflict of interest: The authors declare no potential conflict of interest.

Funding: None.

Received for publication: 5 February 2019.

Revision received: 10 July 2019.

Accepted for publication: 10 July 2019.

This work is licensed under a Creative Commons Attribution NonCommercial 4.0 License (CC BY-NC 4.0).

${ }^{C}$ Copyright: the Author(s), 2019

Licensee PAGEPress, Italy

Pyramid Journal of Medicine 2019; 2:41 doi:10.4081/pjm.2019.41

Asia. ${ }^{8}$ In Ethiopia there were an estimated 4.3 million occupational accidents with over 5596 fatalities annually. This gave accident and fatality rate of 16,426 and 21.5 per 100,000 workers, respectively. $^{8}$ Multiple surveys, however, have confirmed that $20 \%$ of human sicknesses and deaths in some African countries are due to zoonosis, thus African countries constitute $70 \%$ of global hotspots for the prevalence of endemic zoonotic diseases. ${ }^{9}$ Many Nigerians are at risk of contracting abattoir zoonoses through consumption of contaminated meat, and more vulnerable to these are the abattoir workers without protective apparels, leading to exposure to occupational hazards, thus stressing the need for legislations to be put in place by the Government. ${ }^{9}$

In Nigeria, abattoir workers constitute a major group at risk of contracting occupational zoonoses, due to the close contact existing between them and animals/tissues during slaughter and processing. ${ }^{10}$

The working conditions, hygiene and operations of slaughterhouses in most African countries; especially Nigeria, parts of Kenya and Tanzania have not been in compliance with the recommendations of World Trade Organization (WTO), World Organization for Animal Health (OIE), World Health Organization (WHO), Food and Agriculture Organization (FAO) and Codex Alimentarius Commission (CAC), unlike the abattoirs in Europe; where consumers are protected from food-borne zoonoses, by adoption of an integrated approach 
to food safety from farm to the fork through risk assessments and risk management practices. ${ }^{9}$ To ensure proper control of occupational health hazards among the abattoir workers, standard design and good environmental hygiene must be taken into consideration all the time. The use of Personal Protective Equipment (PPE) and other preventive measures should be strongly encouraged. The abattoir management should entail the use of safer equipment that are easy to clean and decontaminate, as well as routine cleaning of all working equipment and surfaces, routine medical surveillance and diagnostic investigations on possible risk exposure to occupational health hazards be conducted as they are important disease control measures. Animal owners and handlers, especially those at risk of lacerations and cuts at their workplaces, should be educated on the importance of vaccinations to prevent them from contracting zoonotic diseases. ${ }^{4}$

The butcher's knowledge and awareness about the hazards of improper meat processing and handling, is essential to safeguard their health as well as the health of the community. ${ }^{11}$

This study therefore aimed to ascertain the knowledge occupational hazards, safety and hygienic practices of butchers in Kano Metropolis with a view of identifying the ways to prevent them. This study can be used to sensitize stake holders so that they can provide support and resources necessary to reduce occupational hazards and improve on safety and hygiene.

\section{Materials and Methods}

\section{Study area/Setting}

The study was carried out in major abattoirs within Kano metropolis. Kano State is located in Northwestern Nigeria. It consists of forty-four (44) Local Government Areas (L.G.As) and had a projected population of $13,065,294$ in $2017 .^{12}$

The Kano metropolis comprises of eight Local Government Areas; Kano Municipal, Fagge, Dala, Gwale, Tarauni, Nassarawa, Ungoggo and Kumbotso. The total land area of Metropolitan Kano is 499 square kilometers with 2,163,225 people as 2006 national population census living within the metropolis using a growth rate of $3.1 \%$ per annum. Kano state, had a projected total population of $11,215,688$ in 2012 and $13,065,294$ in $2017 .{ }^{12}$ There are three major abattoirs namely [kwari or kofar wambai], Unguwa uku, and Mil tara/Bachirawa, within which animals for consumption are slaughtered daily for purchase by butchers from different parts of the metropolis.
Animals are examined locally at the abattoir by the appropriate authority before recommending and eventual slaughter for meat business activities. The butchers in the abattoirs have permanent stations where they engage in the sale of raw meats to both consumers and butchers involved in meat retail activities

\section{Study design}

Descriptive cross-sectional study design was used.

\section{Study population/Inclusion criteria}

The study population comprised of all the butchers in Kano metropolis who have been in the meat business for at least 6 months and are older than 18 years of age. Butchers not in the abattoir during the data collection were excluded.

\section{Sample size determination}

A sample of 321 was determined using an appropriate formula for estimating minimum sample size for descriptive studies. ${ }^{13}$

$$
\mathrm{n}=\frac{\mathrm{Z}^{2} \mathrm{pq}}{\mathrm{d}^{2}}
$$

Standard normal deviate (z) 1.96 at 95\% confidence interval and margin of error (d) 0.05 and prevalence (p) from previous study, ${ }^{14}$ point prevalence rates of Work-Related Muscular Skeletal Disorders) (WRMSDs) among butchers, 74.5\% $=0.745$ obtained from a past study and a nonresponse rate of $10 \%$ were used to compute the sample size.

\section{Sampling technique}

Cluster sampling technique was used for the selection of respondents. The list of the major abattoirs in Kano metropolis was obtained from the Kano state ministry of environment and included; Abattoir (kwari or kofar wambai), Unguwa uku and Mil tara/Bachirawa.

Each of the Abattoirs was considered as a cluster and respondents were equally allocated to consist of 107 respondents in each cluster. All respondents were interviewed in each cluster until the required sample size of 107 was obtained.

\section{Instrument of data collection}

Interviewer administered semi-structured questionnaire with open and close ended questions adapted from previous study ${ }^{13}$ was used to collect data from eligible respondents. The questionnaire consisted of three sections that elicited information on the respondent's socio-demographic data, knowledge of occupational hazard and safety practices among the respondents.

The questionnaire was pretested among 40 butchers in their respective places of business in Kumbotso town. The questionnaires were administered by 9 trained Hausa speaking research assistants and interviews were conducted in Hausa.

\section{Data management and analysis}

Data was analyzed using IBM SPSS

Table 1. Distribution of socio-demograph-

\begin{tabular}{|c|c|c|}
\hline Characteristics & $\begin{array}{c}\text { Frequency } \\
(\mathrm{n}=321)\end{array}$ & $\%$ \\
\hline $\begin{array}{c}\text { Age (years) } \\
10-19 \\
20-29 \\
30-39 \\
40-49 \\
50-59 \\
\geq 60\end{array}$ & $\begin{array}{c}1 \\
78 \\
115 \\
77 \\
41 \\
9\end{array}$ & $\begin{array}{c}0.31 \\
24.30 \\
35.83 \\
23.99 \\
12.77 \\
2.80\end{array}$ \\
\hline $\begin{array}{l}\text { Marital status } \\
\text { Single } \\
\text { Married } \\
\text { Widowed } \\
\text { Divorced }\end{array}$ & $\begin{array}{c}77 \\
236 \\
6 \\
2\end{array}$ & $\begin{array}{c}23.99 \\
73.52 \\
1.87 \\
0.62\end{array}$ \\
\hline $\begin{array}{l}\text { Ethnicity } \\
\text { Hausa } \\
\text { Fulani } \\
\text { Igbo } \\
\text { Yoruba }\end{array}$ & $\begin{array}{c}314 \\
5 \\
1 \\
1\end{array}$ & $\begin{array}{c}97.82 \\
1.56 \\
0.31 \\
0.31\end{array}$ \\
\hline $\begin{array}{l}\text { Level of education } \\
\text { No education } \\
\text { Primary } \\
\text { Secondary } \\
\text { Tertiary } \\
\text { Qur'anic only }\end{array}$ & $\begin{array}{c}14 \\
161 \\
53 \\
11 \\
82\end{array}$ & $\begin{array}{c}4.36 \\
50.16 \\
16.50 \\
3.43 \\
25.55\end{array}$ \\
\hline $\begin{array}{l}\text { Monthly income (na) } \\
1,000-50,000 \\
51,000-100,000 \\
101,000-150,000 \\
151,000-200,000 \\
>200,000\end{array}$ & $\begin{array}{c}217 \\
91 \\
9 \\
3 \\
1\end{array}$ & $\begin{array}{l}67.60 \\
28.35 \\
2.80 \\
0.93 \\
0.31\end{array}$ \\
\hline $\begin{array}{l}\text { Duration of work exp } \\
\quad 1-5 \\
6-10 \\
>10\end{array}$ & $\begin{array}{c}\text { ce (years) } \\
20 \\
44 \\
257\end{array}$ & $\begin{array}{c}6.23 \\
13.71 \\
80.06 \\
\end{array}$ \\
\hline $\begin{array}{l}\text { Hours of work per d } \\
\quad 1-6 \\
7-12 \\
\geq 13\end{array}$ & $\begin{array}{c}130 \\
184 \\
7\end{array}$ & $\begin{array}{c}40.50 \\
57.32 \\
2.18\end{array}$ \\
\hline $\begin{array}{l}\text { How meat preparati } \\
\text { Catering school } \\
\text { Parents } \\
\text { Friends } \\
\text { Self } \\
\text { Others }\end{array}$ & $\begin{array}{c}\text { learnt } \\
2 \\
269 \\
29 \\
17 \\
4\end{array}$ & $\begin{array}{c}0.62 \\
83.80 \\
9.03 \\
5.30 \\
1.25\end{array}$ \\
\hline $\begin{array}{l}\text { Type of meat vending } \\
\text { Restaurant } \\
\text { Meat stall } \\
\text { Open space } \\
\text { Raw meat only }\end{array}$ & $\begin{array}{c}2 \\
29 \\
280 \\
10\end{array}$ & $\begin{array}{c}0.62 \\
9.03 \\
87.23 \\
3.12\end{array}$ \\
\hline
\end{tabular}
ic characteristics of the respondents. 
Statistics for Windows, Version 22 at univariate, bivariate and multivariate levels. Quantitative variables were summarized using appropriate measures of central tendency and dispersion while categorical variables were presented as frequencies and percentages. The dependent/outcome variables are knowledge of occupational hazard and safety practice and while the independent variables are age, highest educational status, tribe, marital status, among others.

Ten questions on Knowledge of occupational hazards were asked, a correct response was scored one point while a wrong response was allocated a zero point. Respondents with knowledge score of (0$3.3),(3.4-6.7)$ and (6.8-10) were considered to have poor, fair and good knowledge of occupational hazards respectively. Knowledge score of occupational hazards was converted to proportion by dividing the score by (10) and multiplied by hundred then categorized into poor, fair and good ( 0 $33 \%, 34-67 \%$ and $>67 \%$ ) respectively.

Twenty-seven questions were asked to assess safety practices among the respondents. Correct answer to each question was awarded one point while wrong response was allocated a zero point. Scores of (0$13.7),(>13.7-27.3)$ and $(\geq 27.4)$ were considered poor, fair and good safety practices respectively. One-way analysis of variance (ANOVA) was used to test for significant association between numerical variables and compared means in more than two groups. Ordinal logistic regression was used to adjust for confounders using the categories calculated based on individual scores. This was aimed at determining the predictors of knowledge of occupational hazards and safety practices. A P-value of $\leq 0.05$ was considered significant. The criteria for inclusion of variable into the ordinal logistic regression model were a priori variable, variables significant on bivariate analysis, and a set $\mathrm{P} \leq 0.1$ for variables that were not significant in bivariate analysis. ${ }^{13}$

\section{Ethical considerations}

Ethical approval was obtained from Kano State Health Research Ethics Committee of Kano State Ministry of Health with approval number of MOH/OFF/797/T.I/787, and advocacy visit was conducted to the leadership of each abattoir during which relevance of the study was explained to them for their cooperation. Data was collected from August to October 2018.All the principles of research ethics were respected throughout the conduct of the research. Consent form was translated to local language (Hausa), literate respondents indicated acceptance by signing the form while the non-literate affixed their thumbprints.

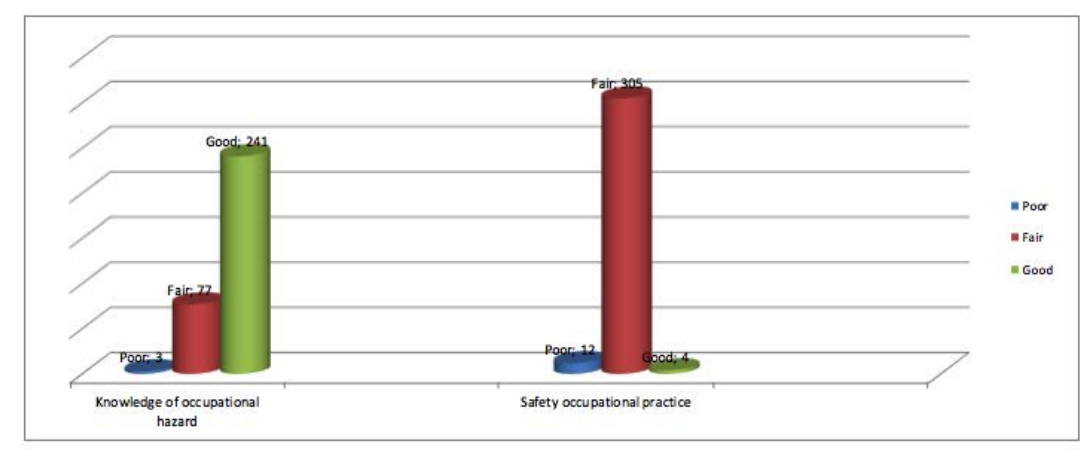

Figure 1. Knowledge of occupational hazard, safety and hygienic practice grade of the respondents.

Table 2. Positive responses to knowledge of occupational hazard and safety practices questions.

\begin{tabular}{|c|c|c|}
\hline Butcher's knowledge of occupational hazard & Frequency $(n=321)$ & $\%$ \\
\hline Do you think there are hazards associated with your work? & 294 & 91.59 \\
\hline $\begin{array}{l}\text { Which of the following is negatively associated with your work? } \\
\text { Cut/injuries } \\
\text { Fall from height } \\
\text { Inhalation of chemicals } \\
\text { Contracting diseases from infected animals } \\
\text { Getting secondary infection from the wound sustained } \\
\text { Slipping from wet floor } \\
\text { Musculoskeletal pain } \\
\text { Animal bite }\end{array}$ & $\begin{array}{l}309 \\
292 \\
293 \\
211 \\
241 \\
292 \\
303 \\
122\end{array}$ & $\begin{array}{l}96.26 \\
90.97 \\
91.28 \\
65.73 \\
75.08 \\
90.97 \\
94.39 \\
38.01\end{array}$ \\
\hline
\end{tabular}

Table 3. Butchers positive responses to safety practices.

\begin{tabular}{lcc}
\hline Butcher's safety practices & Frequency (n=321) & $\%$ \\
Do you carry out meat inspection & 312 & 97.2 \\
Do you practice medical examination & 70 & 21.8 \\
\hline As a meat handler, when should you routinely go for medical check-ups? & & \\
When sick & 304 & 94.70 \\
Quarterly & 9 & 2.80 \\
After every six months & 6 & 1.90 \\
Yearly & 6 & 1.90 \\
Under which of the following conditions do you wash your hands? & & \\
Before commencement of meat preparation? & 293 & 91.3 \\
After preparation of meat: & 278 & 86.6 \\
Before serving each customer: & 45 & 14.0 \\
After touching money: & 74 & 23.1 \\
After visiting the toilet & 308 & 96.0 \\
After handling refuse & 298 & 92.8 \\
If Yes in any above, with what & 114 & 35.5 \\
How often do you clean your work surfaces & 13 & 4.5 \\
How often do you wash your meat preparation utensils & 12 & 3.7 \\
With what do you clean cooking utensils & 273 & 85.1 \\
\hline Which of the following are practice(s) you use while serving your customers? & & \\
Nylon bag & 299 & 93.2 \\
Sheet of papers & 298 & 92.8 \\
Plates/dishes & 1 & 0.31 \\
How do you treat solid waste from your trade? & 29 & 9.0 \\
\hline How do you treat liquid waste from your trade? & 215 & 67 \\
In case you are sick, do you work? & 276 & 86 \\
\hline If no above, what kind of sickness makes you stay at home and not handle meat? & 269 & \\
Fever and headache & 15 & 83.8 \\
Cough/sore throat & 51 & 5.0 \\
Diarrhea & 3 & 16.0 \\
Skin conditions & 6 & 1.0 \\
Others & 2.0 \\
\hline & & \\
\hline
\end{tabular}




\section{Results}

\section{Socio-demographic characteristics} of the butchers

The mean age of the respondents was $37.7 \pm 10.5$ years. More than a third $(35.83 \%)$ of the respondents was between the age ranges of 30 to 39 years. Almost all the respondents were males and Hausa/Fulani by tribe (>99\%). Married respondents constituted more than twothirds $(73.5 \%)$ and about one-half (50.2\%) had primary education as the highest educational qualification. More than two-thirds $(67.6 \%)$ of the respondents had an estimated monthly income of between one thousand to fifty thousand naira with majority (80.1\%) having been in the business for more than ten years. More than half $(57.3 \%)$ use to work for between 7 to 12 hours daily. Most of the butchers $(83.8 \%)$ learnt meat preparation from their parents and conducts the business in an open space $(87.2 \%)$ (Table 1)

\section{Butcher's knowledge of occupation- al hazard}

The mean knowledge score was $7.4 \pm 1.4$. More than three-quarters of the respondents had good knowledge 241 (75\%) of occupational hazard as shown in Figure 1. Risk of cut/injuries was known by

Table 4. Factors associated with knowledge of occupational hazard and safety occupational practices.

\begin{tabular}{|c|c|c|c|c|c|}
\hline \multirow[t]{2}{*}{ Characteristics } & \multirow[t]{2}{*}{$\mathrm{n}=321$} & $\begin{array}{l}\text { Knowledge of } \\
\text { occupational hazard }\end{array}$ & $\begin{array}{l}\text { Logistic } \\
\text { regression }\end{array}$ & $\begin{array}{l}\text { Safety } \\
\text { practices }\end{array}$ & $\begin{array}{l}\text { Logistic } \\
\text { regression }\end{array}$ \\
\hline & & Mean \pm SD $\quad P$-Value & $\begin{array}{l}\text { Adjusted OR } \quad \text { P-Value } \\
(95 \% \mathrm{CI})\end{array}$ & MeantSD P-Value & $\begin{array}{l}\text { Adjusted OR } \\
(95 \% \mathrm{CI}) \quad \mathrm{P}-\mathrm{V}\end{array}$ \\
\hline
\end{tabular}

\begin{tabular}{|c|c|c|c|c|c|c|c|c|c|}
\hline $\begin{array}{c}\text { Age (years) } \\
10-19 \\
20-29 \\
30-39 \\
40-49 \\
50-59 \\
\geq 60\end{array}$ & $\begin{array}{c}1 \\
78 \\
115 \\
77 \\
41 \\
9\end{array}$ & $\begin{array}{l}7 \pm 0.00 \\
7.4 \pm 1.6 \\
7.5 \pm 1.1 \\
7.2 \pm 1.5 \\
7.3 \pm 1.4 \\
7.1 \pm 1.3\end{array}$ & 0.7 & & & $\begin{array}{l}16.0 \pm 0.0 \\
12.0 \pm 3.2 \\
12.0 \pm 2.2 \\
12.4 \pm 2.2 \\
12.4 \pm 2.2 \\
13.1 \pm 2.9\end{array}$ & 0.4 & & \\
\hline $\begin{array}{l}\text { Marital status } \\
\text { Single } \\
\text { Married } \\
\text { Widowed } \\
\text { Divorced } \\
\end{array}$ & $\begin{array}{c}77 \\
236 \\
6 \\
2\end{array}$ & $\begin{array}{l}7.4 \pm 1.5 \\
7.4 \pm 1.3 \\
6.8 \pm 1.2 \\
7.5 \pm 2.1\end{array}$ & 0.8 & & & $\begin{array}{l}12.2 \pm 2.5 \\
12.2 \pm 2.5 \\
11.0 \pm 1.8 \\
12.5 \pm 0.7\end{array}$ & 0.7 & & \\
\hline $\begin{array}{l}\text { Ethnicity } \\
\text { Hausa } \\
\text { Fulani } \\
\text { Igbo } \\
\text { Yoruba }\end{array}$ & $\begin{array}{c}314 \\
5 \\
1 \\
1\end{array}$ & $\begin{array}{l}7.4 \pm 1.4 \\
7.4 \pm 1.5 \\
6.0 \pm 0.0 \\
7.5 \pm 2.1\end{array}$ & 0.8 & & & $\begin{array}{l}12.2 \pm 2.5 \\
13.4 \pm 3.8 \\
13.0 \pm 0.0 \\
12.0 \pm 0.0\end{array}$ & 0.7 & & \\
\hline $\begin{array}{l}\text { Education status } \\
\text { No education } \\
\text { Primary } \\
\text { Secondary } \\
\text { Tertiary } \\
\text { Quranic only }\end{array}$ & $\begin{array}{c}14 \\
161 \\
53 \\
11 \\
82\end{array}$ & $\begin{array}{l}7.6 \pm 1.6 \\
7.6 \pm 1.1 \\
7.1 \pm 1.7 \\
6.7 \pm 2.4 \\
7.0 \pm 1.3\end{array}$ & $0.003 *$ & $1.24(1.02-1.50)$ & $0.03^{*}$ & $\begin{array}{l}12.4 \pm 1.5 \\
12.0 \pm 2.5 \\
12.9 \pm 2.1 \\
12.8 \pm 2.6 \\
12.0 \pm 2.6\end{array}$ & 0.1 & $1.2(0.8-1.75)$ & 0.4 \\
\hline $\begin{array}{l}\text { Monthly income (naira) } \\
1,000-50,000 \\
51,000-100,000 \\
101,000-150,000 \\
151,000-200,000 \\
>200,000\end{array}$ & $\begin{array}{c}217 \\
91 \\
9 \\
3 \\
1\end{array}$ & $\begin{array}{l}7.4 \pm 1.4 \\
7.3 \pm 1.2 \\
8.1 \pm 1.4 \\
7.0 \pm 1.0 \\
6.0 \pm 0.0\end{array}$ & 0.4 & & & $\begin{array}{l}12.2 \pm 2.8 \\
12.2 \pm 1.5 \\
12.3 \pm 2.3 \\
13.0 \pm 1.7 \\
7.0 \pm 0.0\end{array}$ & 0.3 & & \\
\hline $\begin{array}{l}\text { Duration in business (years) } \\
\quad 1-5 \\
\quad 6-10 \\
>10\end{array}$ & $\begin{array}{l}20 \\
44 \\
257\end{array}$ & $\begin{array}{l}7.2 \pm 1.2 \\
7.8 \pm 0.9 \\
7.3 \pm 1.4\end{array}$ & $0.048 *$ & $0.95(0.58-1.55)$ & 0.8 & $\begin{array}{l}12.2 \pm 1.8 \\
11.9 \pm 3.2 \\
12.3 \pm 2.4 \\
\end{array}$ & 0.7 & & \\
\hline $\begin{array}{l}\text { Hours of work per day } \\
\qquad \begin{array}{l}1-6 \\
7-12 \\
\geq 13\end{array}\end{array}$ & $\begin{array}{c}130 \\
184 \\
7\end{array}$ & $\begin{array}{l}7.2 \pm 1.5 \\
7.5 \pm 1.2 \\
8.0 \pm 0.8\end{array}$ & 0.06 & $0.6(0.36-0.99)$ & $0.045^{*}$ & $\begin{array}{l}12.4 \pm 2.3 \\
12.0 \pm 2.6 \\
13.4 \pm 1.6\end{array}$ & 0.2 & $1.9(0.69-5.02)$ & 0.2 \\
\hline $\begin{array}{l}\text { How meat preparation was learnt } \\
\text { Catering school } \\
\text { Parents } \\
\text { Friends } \\
\text { Self } \\
\text { Others }\end{array}$ & $\begin{array}{c}2 \\
269 \\
29 \\
17 \\
4\end{array}$ & $\begin{array}{c}6 \pm 1.4 \\
7.3 \pm 1.4 \\
7.4 \pm 1.2 \\
8.1 \pm 0.6 \\
6.3 \pm 1.5\end{array}$ & $0.005^{*}$ & $0.7(0.39-1.11)$ & 0.12 & $\begin{array}{l}11.5 \pm 5.0 \\
12.2 \pm 2.6 \\
12.3 \pm 1.3 \\
11.9 \pm 1.4 \\
12.5 \pm 3.7\end{array}$ & 1.0 & & \\
\hline $\begin{array}{l}\text { Type of meat vending } \\
\text { Restaurant } \\
\text { Meat stall } \\
\text { Open space } \\
\text { Raw meat only } \\
\end{array}$ & $\begin{array}{c}2 \\
29 \\
280 \\
10\end{array}$ & $\begin{array}{l}7.0 \pm 1.4 \\
6.8 \pm 1.5 \\
7.4 \pm 1.3 \\
6.9 \pm 1.2\end{array}$ & 0.088 & $0.51(0.27-0.98)$ & $0.045^{*}$ & $\begin{array}{l}14.0 \pm 2.8 \\
13.8 \pm 3.3 \\
12.0 \pm 2.3 \\
12.0 \pm 2.3\end{array}$ & $0.003 *$ & $6.85(2.24-21.01)$ & $0.001^{*}$ \\
\hline
\end{tabular}

*Statistically significant 
most of the respondents 309(96.3\%), however, getting secondary infections from sustained wound and contracting diseases from infected animals were known by 241 (75.1\%) and $211(65.7 \%)$ of the respondents respectively as shown in Table 2.

\section{Occupational safety practice}

The mean occupational safety practice score among the respondents was $12.2 \pm 2.5$. Majority of the butchers $305(95.0 \%)$ had fair safety practice as shown in Figure 1.

All the respondents used bare hands in handling meat. None of the respondents correctly responded to question on how leftover meat is being handled. Majority of the respondents 304 (94.7) seek medical examination only when sick as shown in Table 3 .

\section{Discussion}

Safety and hygienic practices among butchers are important in the prevention of food-borne diseases associated with consumption of contaminated meat and preventing butchers from zoonosis and other hazards associated with their occupation. This will be achieved only when the butchers have sound knowledge of the hazards they are exposed to and how to protect consumers from various infection that can be traced to their poor personal and meat hygienic practices

More than three-quarters of the respondents in this study were found to have good knowledge 241 (75\%) of occupational hazard. Cut/injuries was known by most of the respondents 309 (96.3\%), however, getting secondary infections from sustained wound and contracting diseases from infected animals were correctly answered by 241 (75.1\%) and $211(65.7 \%)$ of the respondents respectively. The knowledge of zoonosis was slightly higher than what was obtained in India, that identified $60 \%$ of butchers to be aware of zoonotic diseases. ${ }^{15}$ Much lower level of knowledge of $46.7 \%$ was also identified in another study. ${ }^{16}$ Having better knowledge of being at risk of infection therefore will promote safety practices by the butchers thereby protecting them from negative consequences associated with noncompliance, their family and the community at large.

This study identified that, having at least primary education is associated with $24 \%$ increased likelihood of having good knowledge of occupational hazard $[\mathrm{AOR}=1.24,95 \% \mathrm{CI}=(1.02-1.50)]$ and this may be explained by possibility of learning in school and reading on diseases associated with their occupation (Table 4).

In comparison with a study that found majority $88.09 \%$ of meat handlers to wash their hands after handling waste and $97.62 \%$ after using the toilet, ${ }^{17}$ almost the same $(96.0 \%)$ identified hand washing after visiting the toilet as a key condition to observe hand washing in this study, and practiced by only $14 \%$ of the respondents after serving each customer which was half of $32.73 \%$ of what was obtained among the respondents that accepted no substitute for hand washing in promoting meat safety and hygiene. ${ }^{16}$

A study conducted in India found $51.7 \%$ and $68.3 \%$ of meat handlers to opinioned that they will continue their work when having eczema or diarrhea, ${ }^{16}$ these findings were better than what was identified in this study with only $1 \%$ and $16 \%$ of the respondents staying at home when having skin infection and diarrhea respectively.

A high proportion (62.64\%) of animal handlers admitted to not wearing protective clothing during slaughter ${ }^{18}$ and the meat may be contaminated in a situation where there is poor compliance with hand washing in addition to contracting zoonosis.

Less than one-quarters $(21.8 \%)$ of the respondents in this study responded to conducting medical examination in comparison with what was obtained in Ethiopia that showed $15.4 \%$ of the abattoir workers have no health certificate. ${ }^{19}$ A study conducted in Ghana indicated that using caps, masks, protective gloves and proper clothing can minimize the risk of contamination, ${ }^{20}$ this is in addition to medical examination. The need for training was highlighted in ensuring improved knowledge and safety practices among meat handlers. ${ }^{21,22}$

The finding of this study found a statistically significant association between knowledge of occupational hazard among butchers and being in meat business for between 6-10 years ( $\mathrm{P}=0.048)$, self-learning of meat business $(\mathrm{P}=0.005)$.In addition, working for at least 13 hours in 24 hours was associated with $90 \%$ increased likelihood of having good safety practice $[\mathrm{AOR}=1.9,95 \% \mathrm{CI}=(0.69-5.02)]$.

\section{Conclusions and \\ Recommendations}

Knowledge of occupational hazard was good but the safety practices were not encouraging. Government should ensure enforcement of laws and regular supervision to promote safety practices among the butchers.

\section{References}

1. Awodele O, Popoola TD, Ogbudu BS, et al. Occupational Hazards and Safety Measures Amongst the Paint Factory Workers in Lagos, Nigeria. Saf Health Work 2014;5:106-11.

2. Fasunloro A, Owotade FJ. Occupational Hazards Among Clinical Dental Staff. J Contemp Dent Pract. 2004;5:134-52

3. Diwe $\mathrm{KC}$, Duru CB, Iwu AC, et al. Occupational Hazards, Safety and Hygienic Practices among Timber Workers in a South Eastern State, Nigeria. Occup Dis Environ Med 2016;4:63-71.

4. Abdullahi A, Hassan A, Kadarman N, et al. Occupational hazards among the abattoir workers associated with noncompliance to the meat processing and waste disposal laws in Malaysia. Risk Manag Healthc Policy 2016;9:157-63.

5. World Society for the Protection of Animals. Zoonotic diseases, human health and farm animal welfare. 2013. Available frm: https://www. ciwf.org.uk/media/3756123/Zoonoticdiseases-human-health-and-farm-animal-welfare-16-page-report.pdf

6. Tesfaye D, Fekede D, Worku T, et al. Perception of the public on the common zoonotic diseases in Jimma, Southwestern Ethiopia. Int J Med 2013; 5:279-85.

7. Banjo TA, Onilude AA, Amoo OJ, et al. Occupational Health Hazards Among Abattoir Workers in Abeokuta. Acad Arena 2013;5:29-36.

8. Tadesse S, Bezabih K, Destaw B, Assefa Y. Awareness of occupational hazards and associated factors among welders in Lideta Sub-City, Addis Ababa, Ethiopia. J Occup Med Toxicol 2016;11:15.

9. Fasanmi OG, Ayodeji IO, Oloso NO, Fasina FO. Retrospective studies of abattoir zoonoses in Nigeria: public health implications. CAB Rev 2017; 12:1-14.

10. Abiayi EA, Inabo HI, Jatau ED, et al. Knowledge, attitudes, risk factors and practices (KARP) that favor leptospira infection among abattoir workers in North Central Nigeria. Asian J Epidemiol 2015;8:104-13.

11. Kumar R. Assessment of awareness and hygienic practices among poultry butchers in Patna city, Bihar. 2006. pp 163.

12. Yakubu MJ, Bagavandas M, Dayyabu BI, Daladima NM. Identification of Group Structure among Abattoirs Workers of Kano State Metropolitan , Nigeria based on their KAP Scores in 
Relation to Hygiene Practice: A TwoStep Cluster Analysis. Vet Clin Sci 2016;4:26-32.

13. Lawan UM, Iliyasu Z, Abubakar S, et al. Personal and food hygiene practices of subsistence food vendors operating in Kano metropolis, northwestern Nigeria. Int $J$ Med Sci Publ Health 2015;4:214-21.

14. Kaka B, Idowu OA, Fawole HO, et al. An Analysis of Work-Related Musculoskeletal Disorders Among Butchers in Kano Metropolis, Nigeria. Safe Health Work 2016;7:218-24.

15. Naveen Parahakar Z, Lokesh M, Saidaiah M, Sri Sai E. Awareness Regarding Zoonotic Diseases among the Butchers of Proddatur, Kadapa Dist., A.P., India. Iran J Health Safety
Environ 2016;4:2.729-7.

16. Jianu C, Goleţ I. Knowledge of food safety and hygiene and personal hygiene practices among meat handlers operating in western Romania. J Food Control. 2014;42:214-9.

17. Qekwana D, McCrindle C, Oguttu J, Grace D. Assessment of the Occupational Health and Food Safety Risks Associated with the Traditional Slaughter and Consumption of Goats in Gauteng, South Africa. Int J Environ Res Public Health 2017;14:420.

18. Haileselassie M, Taddele H, Adhana K, Kalayou S. Food safety knowledge and practices of abattoir and butchery shops and the microbial profile of meat in Mekelle City, Ethiopia. Asian Pac J Trop Biomed 2013;3:407-12.
19. Akabanda F, Hlortsi EH, OwusuKwarteng J. Food safety knowledge, attitudes and practices of institutional food-handlers in Ghana. BMC Public Health 2017;17:4021.

20. Neves EG, Cardoso CS, Araújo AC, Correia da Costa M. Meat Handlers training in Portugal: Survey on Knowledge and Practice. Food Control 2010:501-7.

21. Bafanda RA, Khandi SA, Sharma R. Assessment of Existing Meat Handling and Hygienic Practices among Butchers and Meat Retailers in Jammu District of Jammu and Kashmir: A SocioEconomic Analysis. Asian J Agricult Extens Econ Sociol 2017;18:1-9. 